\title{
The diagnosis of primary lung cancer with special reference to sputum cytology
}

\author{
N. C. OS W A L D, K. F. W. H I NSON, G. CA N T I, \\ and A. B. MILLER \\ St. Bartholomew's Hospital, London E.C.I and Brompton Hospital, London S.W.3
}

\begin{abstract}
Of 2,545 in-patients with primary lung cancer, pathological proof of the diagnosis was obtained by sputum cytology in $48 \%$, by bronchoscopy in $32 \%$, by biopsy from miscellaneous sites in $12 \%$, and at thoracotomy or necropsy only in $19 \%$. The diagnosis was made solely on clinical and radiological evidence in $8 \%$.

One or more satisfactory specimens of sputum from 2,035 patients gave a positivity rate of $59 \%$. When three specimens of sputum were tested the positivity rate was $69 \%$ and when four or more were tested, $85 \%$. The maximum false positivity rate was $0.7 \%$. Agreement between the types of malignant cells found in the sputum and in resected or necropsy specimens occurred in $84 \%$. The pathological diagnosis was based solely on sputum cytology in $40 \%$ of the patients in whom malignant cells were found in the sputum.

The total work of the sputum laboratories was analysed for one year (1967); sputum was examined from 1,598 patients, of whom $266(17 \%)$ had positive results.

Of 1,518 patients who had a bronchoscopy, the positivity rate was $53 \%$, and of 524 patients with biopsies from miscellaneous sites the rate was $64 \%$.

Sputum cytology, as practised at present, is a very valuable method of diagnosis, but its demands on time and expertise make it unsuitable for general application outside large medical centres.
\end{abstract}

The diagnosis of primary lung cancer is often obvious after simple clinical and radiological examination, but final proof depends upon the identification of malignant cells. Bronchial biopsies are the standard source of tissue in many hospitals, supplemented by material from lymph nodes, the pleura, and distant metastases. Sputum cytology is capable of yielding many positive results but it is demanding in both time and expertise. The purpose of this article is to analyse current methods of diagnosis at St. Bartholomew's Hospital and Brompton Hospital with particular reference to sputum cytology.

\section{PATIENTS AND METHODS}

The notes of patients admitted to St. Bartholomew's Hospital and Brompton Hospital during the period 1964 to 1969 who had a diagnosis of primary lung cancer at the time of discharge were selected for study. Not included were patients with pulmonary metastases from an extrapulmonary primary site, recurrent primary lung cancer, overnight admissions for bronchoscopy, and those attending for outpatient surveillance only. The notes of 18 patients from St.
Bartholomew's Hospital and 29 from Brompton Hospital could not be traced.

Notes from a total of 2,545 patients were available for study, 913 from St. Bartholomew's and 1,632 from Brompton. There were 2,176 males and 369 $(14 \%)$ females.- One or more specimens of sputum were submitted for cytological investigation from $2,035(80 \%)$ of the patients, bronchoscopy was performed in $1,518(60 \%)$, and biopsies were taken from other sites in $524(21 \%)$. Lung resection was performed in $1,002(39 \%)$ and a further $199(8 \%)$ came to necropsy. A positive pathological diagnosis by means of one or more of these methods was obtained in $2,342(92 \%)$, including $486(19 \%)$ by lung resection or necropsy only. The remaining $203(8 \%)$ were diagnosed by clinical and radiological examination only, no pathological confirmation being obtained. The distribution by cell type for the 2,342 patients was as follows:

$\begin{array}{lrl}\text { Squamous-cell } & 1101 & (47.0 \%) \\ \text { Adenocarcinoma } & 385 & (16.4 \%) \\ \text { Oat-cell } & 400 & (17.1 \%) \\ \text { Undifferentiated } & 386 & (16.5 \%) \\ \text { Unspecified } & 45 & (1.9 \%) \\ \text { Miscellaneous } & 25 & (1.1 \%)\end{array}$

The miscellaneous group included 10 bronchiolo- 
alveolar cell tumours, six carcinoid adenomata, and various sarcomata and lymphomata.

The records of sputum cytology at both hospitals throughout 1967, selected as the mid-year of the study, were also analysed in order to obtain an overall view of the extent to which the test was used as a diagnostic measure. All such records were included, irrespective of the final diagnosis. At least one specimen of sputum from 1,598 patients was examined during 1967, 528 at St. Bartholomew's and 1,070 at Brompton.

In each hospital routine sputum examination was performed on fresh specimens. The staining at St. Bartholomew's was by the method of Papanicolaou (1942) and at Brompton by methylene blue (Schuster, 1947). Three specimens of sputum were considered necessary for diagnosis, examination lasting at least 45 minutes before negative reports were issued.

\section{RADIOLOGICAL APPEARANCES}

Standard postero-anterior and lateral films, often with tomograms in addition, revealed the primary tumour mass in $1,103(43 \%)$ of the patients (Table I). The mass measured more than $2 \mathrm{~cm}$ in diameter in most of these (38\%) and was commonly associated with a hilar opacity. The remaining patients had indirect evidence of lung cancer, in the form of collapse/consolidation/effusion, diffuse shadows or root/mediastinal opacities only. Forty-four $(2 \%)$, all with pathological confirmation of the diagnosis, had postero-anterior films of the chest which showed no suspicion of cancer.

Positive results from sputum cytology were remarkably similar in most radiological groups. The lowest figure (39\%) occurred with rounded opacities up to $2 \mathrm{~cm}$ across compared with $60 \%$ recorded for the larger tumours. This is in keeping with the experience of others (Umiker, 1961 ; Attar, Naib and Cowley, 1961 ; Hattori, Matsuda, Sugiyama and Matsuda, 1964). The 'root/mediastinal only' group, which included many instances of massive mediastinal enlargement, was less con- sistently positive than the group with the larger visible tumours.

Positive bronchoscopic findings were most frequent $(70 \%)$ when the films showed collapse/consolidation/effusion, due to the central location of many of the tumours. The lowest figure $(32 \%)$ was for the smaller and often peripheral tumour masses.

'NO ABNORMALITY' IN RADIOGRAPHS Of the 44 postero-anterior films which showed no sign of cancer, one had old tuberculous scars, one a transient spontaneous pneumothorax, and two evidence of bronchiectasis; the remaining 40 appeared to be normal in every respect. Additional radiographs revealed the cancer in 12 , three in lateral films and nine in tomograms. Of the 44 growths, 32 arose in or near the main bronchi, the diagnosis being confirmed by bronchoscopy (18) and/or sputum cytology (16) or miscellaneous biopsies (4); two were found unexpectedly at necropsy. Pathological proof of the 12 more peripheral growths came from sputum cytology (8), thoracotomy (1), and necropsy (3).

The frequency with which primary lung cancer should be diagnosed without radiological evidence is a matter which is unlikely ever to be satisfactorily determined, since all cancers are radiologically invisible in the first instance. Simon (1966) considers that tumours measuring less than $1.3 \mathrm{~cm}$ in diameter are unlikely to be detected, and Spratt, Ter-Pogossian and Long (1963) estimated that the lower limit of radiographic visibility was a tumour diameter of $0.6 \mathrm{~cm}$ provided that the opacity was not superimposed on a rib. If the growth arises in a main bronchus or within the normal mediastinal and hilar shadows, as it so often does, it may exceed $2 \mathrm{~cm}$ in diameter before it is detected radiologically. Most experienced chest physicians can recollect patients, possibly with an haemoptysis or

T A B L E I

RADIOLOGICAL APPEARANCES AND RESULTS OF SPUTUM CYTOLOGY AND BRONCHOSCOPY

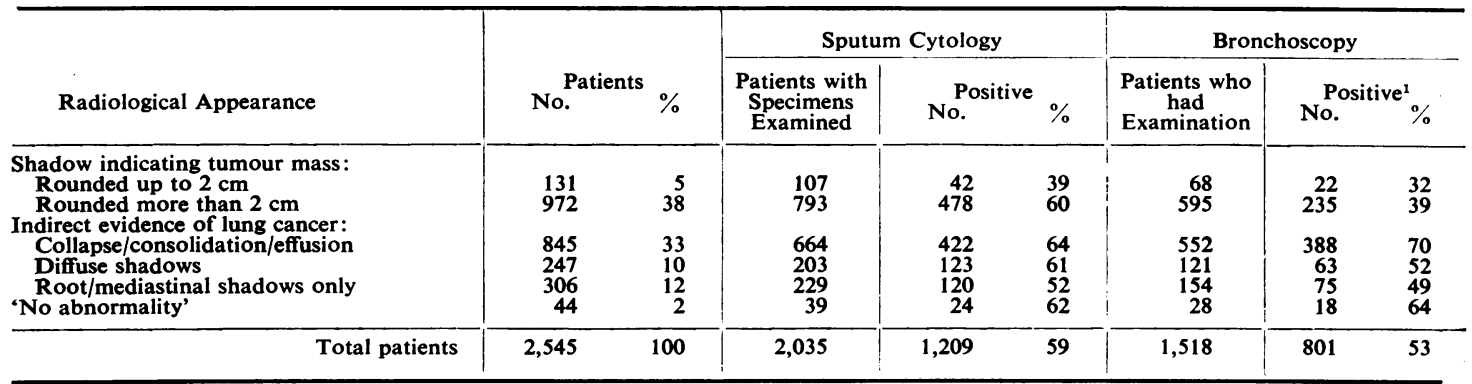

IIncluding 49 patients who had positive 'trap' specimens only. 
vague pains in the chest, who were investigated initially with negative results and then developed radiological signs of cancer at a later date. Twelve patients in the present series followed this sequence. Several authors, reporting small series of pathologically proved lung cancer with negative radiological findings, have stressed the importance of sputum cytology and bronchoscopy in such cases (Woolner, Andersen and Bernatz, 1960 ; Lerner, Rosbash, Frank and Fleischner, 1961 ; Russell et al., 1963 ; Melamed, Koss, and Cliffton, 1963).

\section{SPUTUM CYTOLOGY}

TOTAL EXPERIENCE OF ONE YEAR ONLY (1967) IRRESPECTIVE OF FINAL DIAGNOSIS The total experience in sputum cytology at both hospitals throughout 1967 is set out in Table II. In terms of specimens, the positivity rate was identical $(14 \%)$ in the two hospitals, the lower proportion of patients reported as negative at St. Bartholomew's ( $58 \%$ ), compared with $77 \%$ at Brompton, being offset by the higher proportion of specimens rejected as unsatisfactory for examination at St. Bartholomew's, mainly because they consisted of saliva $(28 \%$ and $9 \%$ respectively). On average a slightly higher number of specimens per patient was examined at St. Bartholomew's, namely $2 \cdot 7$ compared with $2 \cdot 5$ at Brompton. This may explain the slight difference between the two hospitals in the positivity rate for patients, $18 \%$ of 528 at St. Bartholomew's compared with $16 \%$ of 1,070 at Brompton. Combining the results of the two hospitals, $17 \%$ of the 1,598 patients examined were reported as positive for cancer, $75 \%$ as negative and $8 \%$ as submitting only unsatisfactory specimens for testing. (Of the 266 patients with positive sputa, six had primary cancer of the upper air passages or oesophagus and six pulmonary metastases from a distant primary site. In addition to the 4,048 sputa tested, 188 bronchoscopic trap specimens were examined, of which $37(20 \%)$ showed malignant cells.)

These positive results comprise the harvest of sputum cytology, but they must be contrasted with the effort required to examine 2,851 negative specimens. Compared with the 266 cytologically positive patients there were 1,200 with negative sputa. Of these 130 were ultimately diagnosed as having primary lung cancer either by further tests or on clinical grounds alone. The remainder were judged not to have lung cancer; a study of their notes revealed a very wide range of diagnoses, with pneumonia, bronchitis, and heart disease most commonly recorded. Inevitably, if facilities for sputum testing exist, many specimens are sent from patients in whom the possibility of lung cancer is unlikely, often by physicians who are unaware of the time taken to screen negative films.

NUMBER OF SPECIMENS PER PATIENT Of the 2,035 patients in the main study who yielded only one satisfactory specimen of sputum, $832(41 \%)$ were positive (Table III). Of those with one negative specimen, 980 had a second specimen tested of which 180 were positive, giving a cumulative positivity rate for patients with two specimens tested of $56 \%$. Similarly, there was a cumulative positivity rate for three specimens of $69 \%$ and for four or more specimens of $85 \%$.

Table III shows that accuracy in diagnosis increases with the number of specimens tested. Other published series show a similar pattern (Farber et al., 1948 ; Kuesko and Portele, 1949 ; Philps, 1954 ; Meyer and Umiker, 1961 ; Hinson and Kuper, 1963 ; Russell et al., 1963 ; Melamed and Cahan, 1968). Those with the highest positivity rates have tended to be from small numbers of patients. By convention, three satisfactory specimens are needed for a considered cytological opinion, giving a figure for this series of $69 \%$.

The figure of $85 \%$ positive, obtained for patients who had four or more specimens examined, reflects the effort made to achieve positive results in a group of patients in whom the clinical diagnosis of lung cancer was strongly suspected.

T A B L E I I

TOTAL EXPERIENCE OF SPUTUM CYTOLOGY AT BOTH HOSPITALS DURING 1967 IRRESPECTIVE OF FINAL DIAGNOSIS

\begin{tabular}{|c|c|c|c|c|c|c|c|c|}
\hline & Hospital & Total & $\begin{array}{l}\text { Cance } \\
\text { No. }\end{array}$ & $\begin{array}{l}\text { ive } \\
\%\end{array}$ & $\begin{array}{l}\text { Cancer } \\
\text { No. }\end{array}$ & $\begin{array}{l}\text { tive } \\
\%\end{array}$ & $\begin{array}{l}\text { Unsat } \\
\text { Spe } \\
\text { (sali } \\
\text { No. }\end{array}$ & \\
\hline \multirow[t]{2}{*}{ Specimens tested } & $\begin{array}{l}\text { St. Bartholomew's } \\
\text { Brompton }\end{array}$ & $\begin{array}{l}1,417 \\
2,631\end{array}$ & $\begin{array}{l}200 \\
366\end{array}$ & $\begin{array}{l}14 \\
14\end{array}$ & $\begin{array}{r}821 \\
2,030\end{array}$ & $\begin{array}{l}58 \\
77\end{array}$ & $\begin{array}{l}396 \\
235\end{array}$ & $\begin{array}{r}28 \\
9\end{array}$ \\
\hline & Total specimens & 4,048 & 566 & 14 & 2,851 & 70 & 531 & 16 \\
\hline \multirow{2}{*}{$\begin{array}{l}\text { Patients with specimens } \\
\text { examined }\end{array}$} & $\begin{array}{l}\text { St. Bartholomew's } \\
\text { Brompton }\end{array}$ & $\begin{array}{r}528 \\
1,070\end{array}$ & $\begin{array}{r}97 \\
169\end{array}$ & $\begin{array}{l}18 \\
16\end{array}$ & $\begin{array}{l}343 \\
857\end{array}$ & $\begin{array}{l}65 \\
80\end{array}$ & $\begin{array}{l}88 \\
44\end{array}$ & $\begin{array}{r}17 \\
4\end{array}$ \\
\hline & Total patients & 1,598 & 266 & 17 & 1,200 & 75 & 132 & 8 \\
\hline
\end{tabular}


T A B L E I I I

RESULTS OF SPUTUM CYTOLOGY RELATED TO NUMBER OF SATISFACTORY SPUTUM SPECIMENS EXAMINED

\begin{tabular}{|c|c|c|c|c|c|}
\hline $\begin{array}{l}\text { No. of Specimens } \\
\text { per Patient }\end{array}$ & $\begin{array}{c}\text { Patients with } \\
\text { Specimens Examined }\end{array}$ & $\begin{array}{l}\text { Positive } \\
\text { No. }\end{array}$ & $\%$ & Negative & $\begin{array}{l}\text { No. with Negative } \\
\text { Results Re-examined }\end{array}$ \\
\hline $\begin{array}{l}1 \\
2 \\
3 \\
4 \text { or more }\end{array}$ & $\begin{array}{l}2,035 \\
1,812 \\
1,640 \\
1,422\end{array}$ & $\begin{array}{r}832 \\
1,012 \\
1,126 \\
1,209\end{array}$ & $\begin{array}{l}41 \\
56 \\
69 \\
85\end{array}$ & $\begin{array}{r}1,203 \\
800 \\
514 \\
213\end{array}$ & $\begin{array}{r}980 \\
628 \\
296 \\
-\end{array}$ \\
\hline Total & 2,035 & 1,209 & 59 & 826 & - \\
\hline
\end{tabular}

SPUTUM CYTOLOGY IN PATHOLOGICALLY CONFIRMED AND UNCONFIRMED PRIMARY LUNG CANCER In this series, 633 of the patients with cytology specimens examined did not have pathological confirmation of the diagnosis from other material. Of these, 483 $(76 \%)$ were positive on cytology. In contrast, of 1,402 patients who had pathological confirmation of the diagnosis from other material, $726(51 \%)$ were positive on cytology. The principal reason for the higher positive figure on sputum cytology in the unconfirmed group is that, given a reliable cytological service, a definitive diagnosis can often be made by sputum testing alone, and this applies particularly to patients with inoperable disease in whom further pathological confirmation is unnecessary.

The 483 patients in whom the pathological diagnosis was based solely on sputum cytology comprised $40 \%$ of the 1,209 patients with malignant cells in the sputum or $24 \%$ of the 2,035 patients with specimens examined. The existence of this important group of patients in whom the pathological diagnosis is based solely upon sputum testing has been given little recognition in medical literature. Perhaps in order to ensure accuracy in analysis most published reports have included only patients in whom the diagnosis of primary lung cancer has been confirmed by other means, mainly by bronchoscopy or thoracotomy. Davies (1966) lists such data from 25 series extending from the classic paper of Dudgeon and Wrigley (1935) up to 1963 , the rates of positivity varying from $42.8 \%$ to $92.7 \%$ of the patients examined. Grunze (1960) reviewed 29 similar series with $40 \%$ to $90 \%$ positives, giving his own figure of $51 \%$ for 3,662 patients tested. Many of the papers with impressively high rates of positivity have been written by cytologists reporting small personal series or have contained unacceptably high rates of false positives. All are agreed that the greater the number of specimens tested, the greater the likelihood of a positive result, but records of the total number of specimens submitted and the number rejected as unsatisfactory were often omitted from these reports. Latterly, the general opinion seems to be that in a properly conducted laboratory with a skilled cytologist, primary lung cancer is diagnosed by sputum cytology in some $50 \%$ to $60 \%$ of patients tested, with a negligible number of false positives.

SOME DIFFICULTIES IN INTERPRETATION In a series of 2,545 patients with a diagnosis of primary lung cancer on discharge from hospital, there are inevitably some in whom uncertainties arise during the course of diagnosis. The problems of false positives, squamous metaplasia, carcinoma-in-situ, early invasive cancer, and the cytology of chronic pulmonary inflammation are closely connected.

False positives False positives, namely reports of cancer cells in the sputum of patients who do not have cancer, must be sought among the 483 patients in this series with a clinical diagnosis of primary lung cancer in whom the only positive pathological finding was neoplastic cells in the sputum. There were three and at most five patients in whom the possibility of false positive results was identified.

Sputum reports on three of the patients must be regarded as false positives. A man aged 54 had an haemoptysis; "undifferentiated malignant cells' were reported in the first sputum specimen. Over the next two and a half years 10 further sputa and many radiographs of the chest remained negative. A male chronic bronchitic aged 82 had 'unequivocal well-differentiated malignant squames' in one of two specimens. A necropsy six months later showed no sign of cancer. A man aged 64 was known to have had cryptogenic fibrosing alveolitis for three years. Of 10 sputa tested, one showed 'well-differentiated malignant squamous cells' and two 'abnormal squamous cells'. At necropsy there was no sign of cancer. The comment was made subsequently, on reviewing the slides, that the cells were 'not inconsistent with squamous metaplasia'.

Two men aged 61 and 65 , both cigarette smokers with chronic bronchitis, were repeatedly reported as having malignant squamous cells in the sputum (one also had similar cells in a bronchoscopic trap specimen) over a period of two years; radiographs of the chest remained normal. 
Before concluding that they also are false positives, they may be compared with eight other patients who were radiologically negative at the time of the first positive sputum test for malignant cells. The cancer subsequently appeared after intervals of $3,5,6,7,10$ months, 1,4 , and 5 years respectively. In these circumstances it is difficult to refute the opinion of a skilled cytologist who, on reviewing the slides of the two patients quoted reports, 'I cannot alter my view that the cells are malignant'. Indeed, this is the problem posed by most so-called false positives, especially when abnormal squamous cells are found in cigarette smokers or patients with chronically inflamed lungs.

These five patients, compared with the 726 true positives, give a false positivity rate of $0.7 \%(5$ of 731). Similarly, expressed false positives from other centres have varied over the years from $0 \%$ to $7 \cdot 4 \%$ (Davies, 1966), the overall average being about $3 \%$. In this series as a whole there were perhaps $5(0.4 \%)$ in 1,209 patients.

False negatives It is relevant that of 915 patients having one or more satisfactory specimens of sputum tested and who also had a primary lung cancer at surgical resection or necropsy (Table V), 439 or $48 \%$ had negative sputum cytology. The majority were likely to have been negative because there were no malignant cells in the sputum. For this reason no estimate is possible, here or elsewhere, of the frequency of occurrence of false negatives, nor is there any unanimity upon the meaning of the term. To a cytologist it implies that he has failed to see malignant cells when they existed in the specimens provided. In general, experienced cytologists rarely make mistakes provided that the specimen is of good quality, the slides are well prepared, and adequate time is available for examination. This being so, false negativity could equally well be attributed to a clinician's inability to supply a suitable specimen, possibly because the growth is not ulcerating or the bronchus leading to it is obstructed, or because of lack of skill on the part of the nurse or physiotherapist responsible for collecting the specimen.

Squamous metaplasia, carcinoma-in-situ, early invasive cancer In this series sputa were reported as 'positive' or 'negative', sometimes qualified by, for example, 'squamous metaplasia', 'carcinomain-situ', 'more specimens please'. Among the patients with 'positive' reports four who underwent lobectomy may be quoted. Two with normal radiographs and carcinoma-in-situ in bronchial biopsies showed early invasive cancer in the resected specimens. One with long-standing bronchiectasis had a radiologically invisible early invasive cancer. One with doubtful radiological evidence of increased markings in the right lower zone had a normal lower lobe removed, the carcinoma appearing in the opposite lower lobe a year later. An additional patient, not in the series, had a lobectomy on a presumptive diagnosis of lung cancer, but the resected specimen showed tuberculous scars with irregular patches of squamous metaplasia only.

All five patients had in common abnormal squamous cells in the sputum which first suggested the possibility of cancer. The question of squamous metaplasia, carcinoma-in-situ, and early invasive cancer arose in each case, since none had a radiologically visible tumour. After due consideration of such localization of abnormalities as bronchoscopy and radiography afforded, five lobectomies were performed and three small carcinomata were resected. Sputum cytology provided valuable information in each case but did not always indicate the stage of malignant change.

Carcinoma-in-situ is now a well-documented pathological entity (Papanicolaou and Koprowska, 1951; Umiker and Storey, 1952; Raeburn and Spencer, 1953 ; Wierman, McDonald and Clagett, 1954; Cunningham and Winstanley, 1959 ; Canti, 1966). Its differentiation from early invasive cancer by sputum cytology is difficult or impossible, posing particular problems in the interpretation of different types of abnormal squamous cells. Cytologists, quite reasonably, demand short case notes on the patients whose sputa they are testing and they have learnt to be wary in interpreting the degree of malignancy which exists in atypical squames from heavy cigarette smokers and from patients with longstanding pulmonary inflammation.

HISTOLOGICAL TYPE IN SPUTUM COMPARED WITH TYPE IN RESECTED OR NECROPSY SPECIMENS The distribution of types found on sputum cytology differed somewhat from the distribution in the whole series (Table IV): page 623). There was a higher proportion with malignant squamous cells, which were often abundantly exfoliated, many arising from central growths, and also in the readily detected oat cells. Cells from adenocarcinomata, characteristically peripheral growths, were less frequently seen.

There were 476 patients with positive sputum cytology who also had a primary lung cancer at surgical pulmonary resection or necropsy. A considerable measure of agreement existed between 
the cell types from the two sources: for 337 patients with malignant squamous cells in the sputum $300(89 \%)$ were confirmed as squamous on resection or at necropsy, for 29 with adenocarcinoma cells $28(97 \%)$ were confirmed, for 47 with oat cells $37(79 \%)$, and for 39 with undifferentiated cells $22(56 \%)$.

In the series with squamous cells on sputum cytology, resection or necropsy revealed 20 adenocarcinomata. This must be accounted for in part by errors of cytological observation; not infrequently the characteristic clumps of glandular cells are not seen owing to poor differentiation or degenerative changes, and isolated or large malignant cells may at times be taken to represent the commoner malignant squames. There was good correlation with adenocarcinomata. Of 47 reported as containing oat cells, eight were classified as undifferentiated in the resected or necropsy specimen ; in several instances the cytological diagnosis was more likely to have been correct as the histological diagnosis often depended upon material altered by previous radiotherapy or post-mortem autolysis, a sequence which also obtained in several of the patients with malignant squames in the sputum. Of the 39 patients with undifferentiated malignant cells in the sputum, 17 were associated with a differentiated tumour on resection or at necropsy, partly because cells shed into the sputum are often degenerate and tend to appear less differentiated than those in the primary growth.

Some discrepancies between cell types seen in the sputum and in resected or necropsy specimens were due to more than one type being present within the primary growth, but the total cannot be ascertained retrospectively.

SPUTUM CYTOLOGY IN CENTRAL AND PERIPHERAL TUMOURS A precise division into central and peripheral tumours was possible only in those patients $\mathcal{N}$ who had a surgical resection or necropsy. Of 1,201 such patients, 915 had sputum tests, of whom 476 $(52 \%)$ were positive (Table V). Central tumours, arising from the main or lobar bronchi, gave a significantly higher rate of positivity than peripheral tumours, namely $57 \%$ compared with $48 \%$ $(\mathrm{P}<0005)$.

\section{BRONCHOSCOPIC FINDINGS}

Of the 1,518 patients in whom bronchoscopy was performed, no specimen was obtained in 506 $(33 \%)$. The remainder had either a bronchial biopsy or a trap specimen or both; of the 801 positives, 752 were from bronchial biopsies, the other 49 being trap specimens when the biopsy was either negative or not taken. These two types of specimen have both been regarded as positive and are analysed together as a measure of the

T A B L E I V

HISTOLOGICAL TYPE IN SPUTUM COMPARED WITH TYPE IN RESECTED OR NECROPSY SPECIMEN, AND HISTOLOGICAL TYPE ON BRONCHOSCOPY

\begin{tabular}{|c|c|c|c|c|c|c|c|c|c|c|}
\hline \multirow{2}{*}{ Histological Type } & \multirow{2}{*}{\multicolumn{2}{|c|}{$\begin{array}{l}\text { Patients with } \\
\text { Positive Sputum } \\
\text { Cytology } \\
\text { No. }\end{array}$}} & \multirow{2}{*}{$\begin{array}{c}\text { Patients } \\
\text { who had } \\
\text { Resection or } \\
\text { Necropsy }\end{array}$} & \multicolumn{5}{|c|}{ Type in Resected or Necropsy Specimen } & \multirow{2}{*}{\multicolumn{2}{|c|}{$\begin{array}{c}\text { Patients } \\
\text { with Positive } \\
\text { Bronchoscopy } \\
\text { No. } \%\end{array}$}} \\
\hline & & & & Squamous & Adenoca & Oat-cell & $\begin{array}{l}\text { Undiffer- } \\
\text { entiated }\end{array}$ & $\begin{array}{l}\text { Unspeci- } \\
\text { fied }\end{array}$ & & \\
\hline $\begin{array}{l}\text { Squamous } \\
\text { Adenocarcinoma } \\
\text { Oat-cell } \\
\text { Undifferentiated } \\
\text { Unspecified } \\
\text { Miscellaneous }\end{array}$ & $\begin{array}{r}699 \\
117 \\
237 \\
103 \\
49 \\
4\end{array}$ & $\begin{array}{r}58 \\
10 \\
20 \\
9 \\
4 \\
0\end{array}$ & $\begin{array}{r}337 \\
29 \\
47 \\
39 \\
22 \\
2\end{array}$ & $\begin{array}{r}300 \\
1 \\
2 \\
6 \\
3 \\
\end{array}$ & $\begin{array}{r}20 \\
28 \\
8 \\
12 \\
\end{array}$ & $\begin{array}{r}2 \\
37 \\
3 \\
1 \\
-\end{array}$ & $\begin{array}{r}13 \\
22 \\
6 \\
-\end{array}$ & $\frac{2}{E}$ & $\begin{array}{r}476 \\
45 \\
113 \\
151 \\
14 \\
2\end{array}$ & $\begin{array}{r}59 \\
6 \\
14 \\
19 \\
2 \\
0\end{array}$ \\
\hline Total patients & 1,209 & 101 & 476 & 312 & 68 & 43 & 49 & 4 & 801 & 100 \\
\hline
\end{tabular}

Including 49 patients who had positive 'trap' specimens only.

T A B L E V

RESULTS OF SPUTUM CYTOLOGY AND BRONCHOSCOPY RELATED TO SITE OF TUMOUR ON RESECTION OR NECROPSY

\begin{tabular}{|c|c|c|c|c|c|c|c|}
\hline \multirow[b]{2}{*}{ Site of Growth } & \multirow{2}{*}{$\begin{array}{c}\text { Patients who had } \\
\text { Resection or } \\
\text { Necropsy }\end{array}$} & \multicolumn{3}{|c|}{ Sputum Cytology } & \multicolumn{3}{|c|}{ Bronchoscopy ${ }^{1}$} \\
\hline & & $\begin{array}{c}\text { Patients with } \\
\text { Specimens Examined }\end{array}$ & $\begin{array}{l}\text { Positive } \\
\text { No. }\end{array}$ & $\%$ & $\begin{array}{c}\text { Patients who had } \\
\text { Examination }\end{array}$ & $\begin{array}{l}\text { Positive } \\
\text { No. }\end{array}$ & $\%$ \\
\hline $\begin{array}{l}\text { Central } \\
\text { Peripheral }\end{array}$ & $\begin{array}{l}547 \\
654\end{array}$ & $\begin{array}{l}406 \\
509\end{array}$ & $\begin{array}{l}230 \\
246\end{array}$ & $\begin{array}{l}57 \\
48\end{array}$ & $\begin{array}{l}434 \\
435\end{array}$ & $\begin{array}{l}264 \\
123\end{array}$ & $\begin{array}{l}61 \\
28\end{array}$ \\
\hline Total patients & 1,201 & 915 & 476 & 52 & 869 & 387 & 45 \\
\hline
\end{tabular}

${ }^{1}$ Including 49 patients who had positive 'trap' specimens only. 
yield from bronchoscopy. The positivity rate for all bronchoscopies was $53 \%$ and for those in which a specimen was obtained, $79 \%$.

Compared with the cell types for the whole series (Table IV; page 623) bronchoscopy showed the expected excess of squamous carcinomata and a very low figure for the mainly peripheral adenocarcinomata. Central tumours yielded many more positive results than peripheral tumours, namely $61 \%$ compared with $28 \%$ (Table $\mathrm{V})$, a highly significant difference $(\mathrm{P}<0.001)$.

The overall figure for bronchoscopic diagnosis in this series was $801(32 \%)$ in 2,545 patients. When the 49 patients who were positive only on trap specimens are deducted, $752(26 \%)$ were positive on bronchial biopsy. Grunze (1960) recorded $26 \%$ positive bronchial biopsies in a similar large series of patients. Duguid and Huish (1963) obtained $31 \%$ positives in patients with lung cancer admitted to a surgical unit. The highest recorded figure is probably the $45 \%$ positive of Jennings and Shaw (1953) when no less than 379 of a series of 395 patients with lung cancer were bronchoscoped.

COMPARISON OF POSITIVITY ON SPUTUM CYTOLOGY AND BRONCHOSCOPY Comparison between positivity rates for sputum cytology and bronchoscopy, including trap specimens, are hampered by the bias towards bronchoscopy in potentially operable patients and towards sputum cytology in inoperable patients. However, there were 1,207 patients who had one or more specimens of sputum tested and a bronchoscopy. Of those, $648(54 \%)$ were positive on sputum cytology and $602(50 \%)$ on bronchoscopy $(P=0.07)$. Of those with both diagnostic procedures who also proceeded to surgical resection or necropsy, there were 338 patients with central tumours. Of those, $188(56 \%)$ gave positive results for sputum cytology and $202(60 \%)$ for bronchoscopy $(P=0.3)$. In contrast, of the 357 patients with peripheral tumours, $170(48 \%)$ were positive on sputum cytology and $96(27 \%)$ on bronchoscopy $(\mathrm{P}=<0.001)$.

\section{PATHOLOGY OF MATERIAL FROM MISCELLANEOUS} SITES

Table VI lists the sites from which pathological material was obtained, the 335 positive specimens deriving from 317 patients, or $12 \%$ of the whole series.

Enlarged scalene or cervical nodes, with a positivity rate of $90 \%$, were a valuable source of diagnosis and cell typing, especially when sputum cytology was negative; the total of 140 positives represented $4 \%$ of the whole series. Mediastinal nodes also yielded a high number of positives $(69 \%)$. When the indications for node biopsy in lung cancer are extended the positivity rate tends to fall. Grunze (1960) reported $42 \%$ positive when $26 \%$ of 438 patients submitted to the procedure. Positivity rates of $5 \%$ to $25 \%$ have been recorded when impalpable nodes have been removed (Klingenberg, 1964 ; Blair and Hughes, 1966 ; Brantigan and Moszkowski, 1966). Delarue and Strasberg (1966) excised mediastinal nodes from 400 patients with only $30 \%$ positive.

The yield of malignant cells in pleural fluids was low (34\%) and compares unfavourably with the $54 \%$ of Boddington and Spriggs (1965). Pleural needle biopsy gave only $38 \%$ positive results, partly because satisfactory portions of pleura were not always obtained ; Donohue, Katz, and Matthews (1958) obtained $38 \%$ positives from a similar series. Open pleural biopsy with the excision of a much larger specimen gave $80 \%$ positive results.

\section{T A B L E V I}

PATHOLOGY OF MATERIAL FROM MISCELLANEOUS SITES

\begin{tabular}{|c|c|c|c|c|c|c|}
\hline \multicolumn{2}{|l|}{ Site } & & & $\begin{array}{l}\text { No. of } \\
\text { Patients }\end{array}$ & \multicolumn{2}{|c|}{$\begin{array}{l}\text { Positive } \\
\text { No. } \%\end{array}$} \\
\hline $\begin{array}{l}\text { Cervical node } \\
\text { Mediastinoscopy noc } \\
\text { Node, axilla or groin } \\
\text { Pleural fluid } \\
\text { Pleural needle biopsy } \\
\text { Pleural open biopsy } \\
\text { Lung needling } \\
\text { Open lung biopsy } \\
\text { Skin and subcutaneo } \\
\text { Bone .. } \\
\text { Bone marrow } \\
\text { Brain .. } \\
\text { Cerebrospinai fluid } \\
\text { Liver biopsy . } \\
\text { Ascites } \\
\text { Pericardial fluid } \\
\text { Urine . . } \\
\text { Adrenal mass }\end{array}$ & 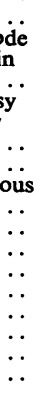 & $\begin{array}{l}\cdots \\
\cdots \\
\cdots \\
\cdots \\
\cdots \\
\cdots \\
\cdots \\
\cdots \\
\cdots \\
\cdots \\
\cdots \\
\cdots \\
\cdots \\
\cdots\end{array}$ & $\begin{array}{l}\cdots \\
\cdots \\
\cdots \\
\cdots \\
\cdots \\
\cdots \\
\cdots \\
\cdots \\
\cdots \\
\cdots \\
\cdots \\
\cdots \\
\cdots\end{array}$ & $\begin{array}{r}158 \\
35 \\
17 \\
108 \\
81 \\
15 \\
13 \\
7 \\
36 \\
11 \\
7 \\
8 \\
8 \\
9 \\
3 \\
3 \\
3 \\
2\end{array}$ & $\begin{array}{r}140 \\
24 \\
10 \\
37 \\
31 \\
12 \\
12 \\
6 \\
29 \\
10 \\
3 \\
6 \\
1 \\
8 \\
2 \\
2 \\
2 \\
0 \\
2\end{array}$ & $\begin{array}{c}90 \\
69 \\
(59) \\
34 \\
38 \\
(80) \\
(92) \\
(86) \\
81 \\
(91) \\
(43) \\
(75) \\
(12) \\
(89) \\
(67) \\
(67) \\
(0) \\
(100)\end{array}$ \\
\hline Total patients & $\ldots$ & $\ldots$ & $\ldots$ & 524 & 335 & 64 \\
\hline
\end{tabular}

Figures in parentheses indicate percentages based on less than 2.5 observations.

Lung needling was infrequently performed, being virtually reserved for inoperable peripheral growths, and gave the anticipated high rate of positivity (Adamson and Bates, 1967; Steel and Winstanley, 1969).

Most of the remaining specimens listed in Table VI derived from the wards of St. Bartholomew's and illustrate the many ways in which pathological material may become available in a general hospital, with significant contributions from the departments of dermatology and neurosurgery. 


\section{DISCUSSION}

The value of sputum cytology, as judged by the number of positive results it produces, is considerable when sufficient satisfactory specimens are forthcoming; the figure of $85 \%$ for four or more specimens (Table IV) is comparable with the experience of many others. When analysis is extended to all patients submitting at least one satisfactory specimen the positivity rate falls, in this series to $59 \%$. There are several reasons for this. Ordinarily, when carcinoma is suspected three specimens are ordered, but as many as three may not be obtainable or some may consist of no more than saliva ; $8 \%$ of the total patients examined in 1967 in this study produced only unsatisfactory specimens. Often bronchoscopy or thoracotomy is undertaken before the results of sputum tests are known, so that no further specimens are sent for examination. In addition, $12 \%$ of the patients in the main study did not have any sputum tests ; some were very ill or moribund on admission, others had no sputum. Hence the practical value of sputum cytology falls short of its theoretical potential and a high rate of positivity can be achieved only when every effort is made to ensure that the number and quality of the specimens submitted are adequate.

The number of false positives must be well below $1 \%$ if clinicians are to have confidence in the reports; in this series it was probably less than $0.7 \%$. However, some latitude must be allowed in the interpretation of reports of abnormal squamous cells in the sputum of heavy smokers and patients with chronic pulmonary inflammation. Discrepancies between cell types in the sputum and in resected or necropsy specimens are inevitable at times, amounting in this series to $87(16 \%)$ of 476 reports (Table IV); the causes are well-recognized, such as the tendency for cells in the sputum and pulmonary metastases to appear less well differentiated than those in the primary growth and the occasional coexistence of different cell types in the primary tumour. The most serious discrepancy from the practical standpoint would be the misreporting of oat cells in the sputum, since this type of growth is now rarely resected ; fortunately their features are characteristic and mistakes are rare.

Bronchoscopy is obviously a very important method of diagnosis. In practice it yields as many positive results as sputum cytology in central growths but is much less efficient in the peripheral variety (Table $\mathrm{V}$ ), although indirect evidence of lung cancer may be obtained. It is necessarily an uncomfortable procedure but it often identifies and localizes a growth which cannot be proved $\overline{\bar{s}}$ by other means. The maximum positive yield $\overparen{\Phi}$ from bronchial biopsy seems to be about $45 \%$ 응 (Jennings and Shaw, 1953) with a small addition क from trap specimens. Pathological material from $\overrightarrow{0}$ miscellaneous sites is sometimes all that is avail- $\vec{\overrightarrow{ }}$ able for a firm diagnosis ; a positive result usually $\vec{\omega}_{\vec{\sigma}}$ indicates that the growth is beyond the stage of $\underset{\overrightarrow{2}}{\overrightarrow{2}}$ operability.

Sputum cytology has obvious advantages over $\stackrel{\sim}{\sim}$ other methods of diagnosis. It is quick and devoid os of trauma and is the test most likely to give a positive result. At times it may be life-saving in 은 terms of early diagnosis. For patients whose disease has proceeded beyond the limits of effec- $z$ tive therapy, it is an ideal way of establishing the diagnosis. Unfortunately, it is very demanding in $\stackrel{\mathbb{D}}{3}$ both laboratory time and expertise. A skilled $\underset{\mathbb{D}}{\overrightarrow{0}}$ cytologist cannot be expected to search microscope slides efficiently for more than about four $\vec{v}$ and a half hours a day. In this time he might.examine 8 to 10 specimens of sputum. The number of positives he finds is likely to be about 15 to $20 \%$, with three-quarters of the specimens coming from patients who do not have lung cancer (Table II). For these reasons sputum $\stackrel{\varnothing}{\varnothing}$ cytology, as practised at present, is unlikely to be adopted as a routine procedure outside large medical centres. Attempts to save time and cost have so far proved disappointing. Technicians may prepare slides and 'screen off' negatives; in rare instances they have become competent cytotechnicians, but the opportunities for them to do so are few. There are many difficulties facing the development of automated cytological screening. Malignant cells may be large or small, are often degenerate, and their nuclei vary in size ; the requirement is a method of identifying the ratio of nuclear to cell size. At least two systems based on microspectrophotometric analyses of cells are currently being developed (Kamentsky and Melamed, 1969 ; Finkel, Grand, Ehrlich, and N DeCote, 1970). The hope is that a system will N eventually be devised which will bring the benefits of sputum cytology to a much greater number of patients than is possible at present.

We wish to thank the physicians and surgeons of St. Bartholomew's and Brompton Hospitals for permission to include their patients.

\section{REFERENCES}

Adamson, J. S., and Bates, J. H. (1967). Percutaneous needle biopsy of the lung. Arch. intern. Med., 119, 164. 
Attar, S., Naib, Z. M., and Cowley, R. A. (1961). Exfoliative cytology in solitary peripheral lesions of the lungs. J. thorac. cardiovasc. Surg., 42, 168.

Blair, C. R., and Hughes, J. H. (1966). Scalene node biopsy: a re-evaluation. J. thorac. cardiovasc. Surg., 52, 595.

Boddington, M. M., and Spriggs, A. I. (1965). Cytological diagnosis of cancer: its uses and limitations. Brit. med.J., $1,1523$.

Brantigan, O. C., and Moszkowski, E. (1966). Bilateral biopsy of non-palpable cervical lymph nodes: diagnosis and prognosis in carcinoma of the lung. Dis. Chest., 50, 464.

Canti, G. (1966). Carcinoma-in-situ of the bronchus. In Some Aspects of Carcinoma of the Bronchus: A Symposium, ed. D. Teare and J. Fenning, p. 41. King Edward VII Hospital, Midhurst, England.

Cunningham, G. J., and Winstanley, D. P. (1959). Hyperplasia and metaplasia in the bronchial epithelium. Ann. roy. Coll. Surg. Engl., 24, 323.

Davies, D. F. (1966). A review of detection methods for the early diagnosis' of lung cancer. J. chron. Dis., 19, 819.

Delarue, N. C., and Strasberg, S. M. (1966). The rationale of intensive preoperative investigation in bronchogenic carcinoma. J. thorac. cardiovasc. Surg., 51, 391.

Donohue, R. F., Katz, S., and Matthews, M. J. (1958).

Pleural biopsy as an aid in the etiologic diagnosis of pleural effusion: review of the literature and report of 132 biopsies. Ann. intern. Med., 48, 344.

Dudgeon, L. S., and Wrigley, C. H. (1935). On the demonstration of particles of malignant growth in the sputum by means of the wet-film method. J. Laryng., 50, 752.

Duguid, H. L. D., and Huish, D. W. (1963). Clinical evaluation of cytodiagnosis in bronchial carcinoma. Brit. med. J. 2, 287.

Farber, S. M., Benioff, M. A., Frost, J. K., Rosenthal, M., and Tobias, G. (1948). Cytologic studies of sputum and bronchial secretions in primary carcinoma of the lung. Dis. Chest, 14, 633.

Finkel, G. C., Grand, S., Ehrlich, M. P., and DeCote, R. (1970). Cytologic screening automated by cytoscreener. J. Ass. Adv. med. Instru., 4, 3.

Grunze, H. (1960). A critical review and evaluation of cytodiagnosis in chest diseases. Acta cytol. (Philad.), 4, 175.

Hattori, S., Matsuda, M., Sugiyama, T., and Matsuda, H. (1964). Cytologic diagnosis of early lung cancer: brushing method under X-ray television fluoroscopy. Dis. Chest, 45, 129.

Hinson, K. F. W., and Kuper, S. W. A. (1963). The diagnosis of lung cancer by examination of sputum. Thorax, 18, 350.

Jennings, R. C., and Shaw, K. M. (1953). The value of cytological examination of the sputum in the diagnosis of carcinoma of the bronchus. Thorax, 8, 288.

Kamentsky, L. A., and Melamed, M. R. (1969). Instrumentation for automated examinations of cellular specimens. Proc. IEEE, 57, 2007.
Klingenberg, I. (1964). Histopathologic findings in the prescalene tissue from 1,000 post-mortem cases. Acta chir. scand., 127, 57.

Kuesko, L., and Portele, K. (1949). Über den Nachweis von Tumorzellen im Sputum. Krebsarzt, 4, 183.

Lerner, M. A., Rosbash, H., Frank, H. A., and Fleischner, F. G. (1961). Radiologic localization and management of cytologically discovered bronchial carcinoma. New Engl. J. Med., 264, 480.

Melamed, M. R., and Cahan, W. G. (1968). Cytology In Lung Cancer, edited by W. L. Watson, p. 205. Mosby, St. Louis.

—, Koss, L. G., and Cliffton, E. E. (1963). Roentgenologically occult lung cancer diagnosed by cytology: report of 12 cases. Cancer (Philad.), 16, 1537.

Meyer, J. A., and Umiker, W. O. (1961). A review of problems relating to the "diagnostic triad" in lung cancer. Surg. Clin. N. Amer., 41, 1233.

Papanicolaou, G. N. (1942). A new procedure for staining vaginal smears. Science, 95, 438.

- and Koprowska, I. (1951). Carcinoma in situ of the right lower bronchus. Cancer (Philad.), 4, 141.

Philps, F. R. (1954). The identification of carcinoma cells in the sputum. Brit. J. Cancer, 8, 67.

Raeburn, C., and Spencer, H. (1953). A study of the origin and development of lung cancer. Thorax, 8, 1.

Russell, W. O., Neidhardt, H. W., Mountain, C. F., Griffith, K. M., and Chang, J. P. (1963). Cytodiagnosis of lung cancer: a report of four year laboratory, clinical and statistical study with a review of the literature on lung cancer and pulmonary cytology. Acta cytol. (Philad.), $7,1$.

Schuster, N. H. (1947). Carcinoma cells in sputum and pleural fluid. In Recent Advances in Clinical Pathology, edited by S. C. Dyke, 1st ed., p. 316. Churchill, London.

Simon, G. (1966). In Some Aspects of Carcinoma of the Bronchus: A Symposium, ed. D. Teare and J. Fenning, p. 87. King Edward VII Hospital, Midhurst, England.

Spratt, J. S., Ter-Pogossian, M., and Long, R. T. L. (1963). The detection and growth of intrathoracic neoplasms. Arch. Surg., 86, 283.

Steel, S. J., and Winstanley, D. P. (1969). Trephine biopsy of the lung and pleura. Thorax, 24, 576.

Umiker, W. O. (1961). The current role of exfoliative cytopathology in the routine diagnosis of bronchogenic carcinoma. Dis. Chest, 40, 154.

- and Storey, C. (1952). Bronchogenic carcinoma in situ. Cancer (Philad.), 5, 369.

Wierman, W. H., McDonald, J. R., and Clagett, O. T. (1954). Occult carcinoma of the major bronchi. Surgery, 35, 335.

Woolner, L. B., Andersen, H. A., and Bernatz, P. E. (1960). "Occult" carcinoma of the bronchus: a study of 15 cases of in situ or early invasive bronchogenic carcinoma. Dis. Chest, 37, 278. 